\title{
QUEEN'S
UNIVERSITY
BELFAST
}

\section{Zero-sum politics in contested spaces: The unintended consequences of legislative peacebuilding in Northern Ireland}

McDowell, S., Braniff, M., \& Murphy, J. (2017). Zero-sum politics in contested spaces: The unintended consequences of legislative peacebuilding in Northern Ireland. Political Geography, 61, 193-202. https://doi.org/10.1016/j.polgeo.2017.09.001

Published in:

Political Geography

Document Version:

Peer reviewed version

Queen's University Belfast - Research Portal:

Link to publication record in Queen's University Belfast Research Portal

Publisher rights

(c) 2017 Elsevier Ltd. This manuscript version is made available under the CC-BY-NC-ND 4.0 license http://creativecommons.org/licenses/by$\mathrm{nc}-\mathrm{nd} / 4.0 /$, which permits distribution and reproduction for noncommercial purposes, provided the author and source are cited.

\section{General rights}

Copyright for the publications made accessible via the Queen's University Belfast Research Portal is retained by the author(s) and / or other copyright owners and it is a condition of accessing these publications that users recognise and abide by the legal requirements associated with these rights.

Take down policy

The Research Portal is Queen's institutional repository that provides access to Queen's research output. Every effort has been made to ensure that content in the Research Portal does not infringe any person's rights, or applicable UK laws. If you discover content in the Research Portal that you believe breaches copyright or violates any law, please contact openaccess@qub.ac.uk. 
Zero-sum politics in contested spaces: The unintended consequences of legislative peacebuilding in Northern Ireland

\begin{abstract}
Studies of ethno-nationalist conflict have repeatedly underlined the significance of policy interventions that seek to de-territorialise contested space after armed conflict and create more plural societies. Creating 'shared' space in divided societies is often critically important and inextricably linked to peacebuilding. However much of this scholarship has tended to focus on the relative success or failure of such policies. This paper conversely explores the 'unintended consequences' (Merton 1936) of legislating around fragile public space in Northern Ireland and considers its potential to undermine, rather than reinforce efforts to transition to peace. Drawing on a body of work around unintended consequences, territorial socialisation and peacebuilding, we argue that such legislation in ethno-nationalist societies emerging from conflict is a double-edged sword which can be utilised both explicitly and implicitly to reactivate tribal spatial politics and exacerbate divisions in deeply divided societies.
\end{abstract}

Keywords: Unintended consequences, conflict, legislation, territorial socialisation, peacebuilding, Northern Ireland 


\section{Introduction}

In societies emerging from conflict, place and its territorial significance represents an acute challenge to successful conflict transformation endeavours (Graham and Nash 2006; Ryan 2016; Vallacher et al, 2010). The development of legislation around spacesharing and symbolic attribution is one common device used to underpin a volatile political transition and to protect citizens' rights as a peace process unfolds (Loncar 2016; MacGinty and Richmond 2013). Such regulation is often bound up in efforts to alter the ways in which citizens navigate, interpret and experience specific places and to create a more plural, tolerant society where territory is still contested (see Bekoe 2016; Sriram 2016; Svensson 2013). However, even legislative frameworks, which are unambiguously grounded in attempts to promote and protect rights in a peacebuilding context, can, we argue, be used as devices to perpetuate the very conflict they seek to ameliorate.

We suggest that within divided societies, peacebuilding legislation can at particular points and in particular places, reactivate and maintain conflict between and across warring parties or actors, placing additional stresses on public bodies who are often tasked with managing disputes (Bollens 2012; Calame and Charlesworth 2009; Fagan and Sircar 2015; Morrissey and Gaffikin 2006). Such legislation can come to represent another conflict theatre, constituting almost a 'war by other means' where the conflict continues to play out on a number of different scales. This creates a significant threat to nascent peace processes, underlining Koopman's $(2017,1)$ assertion that 'war is inside peace, and peace is inside war'. More broadly, contemporary scholarship on peacebuilding has focused on the unintended impacts of interventions, with the bulk of this debate centring on critically engaging with liberal peace approaches and practices (Daase and Friesendorf 2010; Lekha Siram 2007; MacGinty and Richmond 2007). Less attention has been paid to legislation that is specifically designed to build peace and better relations, but is used by ethno-nationalist actors to exacerbate conflict dynamics through claiming and contesting territory. Employing a case study approach drawing on patterns of conflict in Northern Ireland, we unpack the complex relationship between legislating for peace and spatial contestation, extending theoretical constructs around unintended consequences to the new realm of peacebuilding and public space. 
The nuanced and complex relationship between peace and space has according to the Megoran (2011), enjoyed decidedly less focus and attention than the geographies of conflict and violence, despite important efforts by Mamadoth (2005), Flint (2005) and Kobayashi (2009) to open up a conversation. Since 2011, a number of geographers have been instrumental in calling for a much more critical appraisal of spatial practices within the field of peacebuilding, urging scholars to more fully theorise peace using a spatial lens and to consider what peace means and how it takes place across a range of scales (Megoran 2011; Koopman 2011; Lloyd 2012; Williams and McConnell 2011). Thinking about space within the context of peacebuilding and about what 'peace equates to for different stakeholders' (Brickhill 2015, 321) has become acutely important in advancing our understanding of conflict dynamics as key edited volumes from McConnell et, al. (2014) and Björkdahl and Buckley-Zistley (2016) attest. Interrogating spatial practices in the wake of violence is critically important 'for the interpretation of peace. What looks like peacemaking from one perspective and scale, is more problematic from other perspectives' (Richmond, 2014, xvii).

Accepting that peace processes operate along a continuum and may progress and regress across time and space, we like others, conceptualise peace as something that is not necessarily static and finite. We concur with the likes of Ross (2011), Koopman (2017), Shimada (2014) and Williams (2015) that peace, like war, can occur at different scales, places and times. This is certainly true of our case study, Northern Ireland. Writing in 2007 almost a decade following the signing of the 1998 Belfast/Good Friday Agreement which sought to draw a line under three decades of armed conflict, Shirlow and Murtagh (2006) suggested that its largest city Belfast was moving at a 'twin speed'. While many of its citizens were enjoying a liberal peace and economic prosperity, others lived in the shadows of peacewalls built post-agreement to manage sectarian hostilities between ethno-nationalist communities feeling disempowered and removed from the political process. There can be little doubt that peacebuilding has advanced peace in relation to some structural inequalities (such as fair employment, security sector reform and the provision of services) and the work undertaken within and across the community sector has made tremendous progress in transforming difficult and hostile relationships in some places. Despite this, Northern Ireland remains a deeply divided and segregated society where zero-sum politics can resurface, threatening to undermine a fragile peace. 
For the purposes of this paper, we examine the implementation of Section 75 of the Northern Ireland Act 1998 - the so called 'Equality and Good Relations' duties. We suggest that while legislation was developed and designed to underpin peace and produce a plural society, it has also been utilised to undermine peacebuilding efforts, specifically where the territorial socialisation of place remains crucially important to the proponents of single-identities. In doing so, we extend the conceptual framework around 'unintended consequences' from general debates about policy intervention (Talberg 2002), to the new realm of peacebuilding and peacebuilding legislation around territory and space. The paper begins by establishing a theoretical framework around spatial contestation, unintended consequences and peacebuilding, before outlining the context, case selection and methodology. It goes on to discuss the Northern Ireland cases, before drawing conclusions about the significance of the Northern Ireland experience to other contested environments.

\section{Territorial socialisation, zero-sum conflict and legislative peacebuilding}

Within ethno-nationalist societies, divergent interpretations of place often form the crux of intractable conflict (Diehl 1999; Grosby 2005; Newman 2006; Passi 1999). Place is critically important because ethno-nationalist identities are inexorably bound to a specific territory of either discursive or material value. While hard lines and physical borders demarcate the territorial boundaries of many nationalist doctrines it is the symbolic properties of place that give it meaning and contribute to a sense of ownership among its members. Grosby $(1995,60)$ for example suggests that a territory is not simply a space where physical actions take place or are performed; it is rather a "structural, symbolic condition which has significance for those who act within it and towards it". Walter (cited in Gebrewold 2016, 16) agrees, attesting 'territorial attachment and people's willingness to fight for territory have much less to do with the material value of land and much more to do with the symbolic role it plays in constituting people's identities and providing a sense of security and belonging'.

Ethno-nationalist groups engage in a process of 'territorial socialisation' (see Duchacek 1970; Newman 1996; Newman and Paasi 1998; Newman 2006) which involves deliberately cultivating an emotive attachment to a specific territory among members. This can be done through enacting or incorporating forms of 'banal nationalism' (Billig 
1995) in the everyday, such as flying flags, wearing emblems, singing 'national' songs and engaging in sporting events. Alternatively, it may involve more direct or aggressive acts of territoriality such as street-naming (Azarahyu 1996; Alderman 2003), building monuments or memorials (Johnson 1995; Till 2003), parading (Cohen 2007), the use of architecture (Pullan and Gwizada 2009) or the construction of walls or borders (Blackman 2006). Such activities all involve an implicit or explicit emphasis on the territory's historical or mythical importance to the group. For Diehl (1999), they represent a form of 'territorial indoctrination' that embed (a specific group of) people within the spaces they inhabit. Territorial socialisation can be hugely controversial and occasion conflict; as a boundary making practice (Newman 1999) it is designed not only to delineate boundaries for the group within, but to very clearly articulate boundaries for those on the outside.

In ethno-nationalist societies like Northern Ireland where competing interpretations of place provide the backdrop for persistent conflict, post-agreement wrangling over territory and the right to belong often continue to present formidable challenges to peacebuilding and can subvert macro politics (McDowell and Braniff 2014). These challenges, which often revolve around the symbolic importance of territory, become particularly acute whenever legislation designed to minimise conflict is employed in localised territorial struggles under the guise of human or equal rights. While there is a burgeoning literature on the multi-layered processes of de/territorialising place within transitional ethno-nationalist societies (Basch et al, 2003; Hess and Korf 2014; Klem 2014; Tzafadia 2008), there is a notable absence of academic interrogation of the very complex role that peacebuilding legislation plays in facilitating territorial game-playing or point-scoring in a post-conflict context, and enabling the conflict to continue by other means.

In ethno-political conflicts, peace agreements and political settlements are often used to minimise and transform the antagonism between rival ethno-nationalist groupings and to de-territorialise the conflict (Graham and Nash 2006). However, the nature of zero-sum politics in some societies means that peace agreements rarely deliver the demands or political aspirations of warring ethno-nationalist groups (Bell and O'Rourke 2010). Nurturing a continued narrative of attachment to a place designated as symbolic of a group's territory whenever there is a pressure to 'share' and/or de- 
territorialise space is, we argue, fundamentally important to those who already feel they are sacrificing or at least compromising their political objectives as part of a peace agreement. Set against this context, legislating how citizens may or may not use place in the aftermath of conflict, is inherently challenging (Boudon 1977; Elster 1990). In societies emerging from violent conflict, the legislative impetus is firmly tilted towards peacebuilding. However, when the implementation of such policies have unanticipated effects, the impact on peace and conflict can be significant.

Unanticipated or unintended consequences can be defined as an 'effect of purposive social action which is different from what was wanted at the moment of carrying out the act, and the want of which was a reason for carrying it out' (Baert 1991, 201). We approach unintended consequences in a way that moves beyond 'blowback' or negative framing and consider the possibility of desirable and undesirable unintended consequences (Daase and Freisendorf 2010, 9). In doing so, we extend existing policy and peacebuilding debates by demonstrating that peacebuilding legislation can often work to produce both desirable and undesirable results simultaneously for contending parties within the context of intractable conflict. In this regard, unintended consequences are not judged as policy failures (Rhodes 1997) but instead as the byproducts of the politics of contention (Fischer 2003; Pugh et al, 2016; Tarrow 2001). In a seminal contribution, Merton (1936) contends that any social purposive action carries the potential for unintended consequences and unintentional effect. Largely employed to critique government policy, scholarship in this area has tended to focus on five key values: ignorance; assessment; imperious immediacy of interest; basic values and selfdefeating prediction (Merton 1936). When considering peacebuilding legislation, we reflect on the resonance of these key factors to assess the ways in which unintended consequences unfold. Often the undesirable impacts of legislation in the context of societies emerging from violent and bloody conflict can arguably be understood as 'fire-fighting' attempts at public policy formulation. In other words, when framing policy, policy-makers do not have the time, space or opportunity to consider fully the impact of their work and if they had 'spent enough time designing future policies, they could have avoided errors and preoccupations' (Minow 1996, 904). Such idealistic interpretation of the political process negates the nature of power dynamics within ethno-nationalist societies, which is much less straightforward and uncontested in a zero-sum context (Maney et al, 2006). At the heart of this issue lies the clash between 
pursuing a policy of peace founded upon equality between contending groups, whilst remaining cognisant of the persistent power dynamics and latent aggression between conflicted groups. At times overt peacebuilding legislation can itself be 'weaponised' to work against the creation of a plural society. To recognise and mitigate the potential unintended consequences of peacebuilding legislation is to be dichotomously futureproofing and future-forming. Both are problems of policy formation: to consider the wider implications of legislation and how the legislation can be monopolised and manipulated particularly in a no win environment.

The challenges of devising legislation in a post-agreement context are well documented, as are the difficulties of implementation. In identifying the designimplementation gap created through international peacebuilding models, Chandler (2006) and Pugh (2010) evidence negative and unintentional effects of international liberal peacebuilding practices. Not disputing the disconnect between hierarchies of power within any given peacebuilding context, this paper focuses mainly on the national level, not internationally directed processes. From this field of scholarship, a central argument emerges: Visoka $(2016,35)$ contends that the phenomenon of unintended consequences 'neutralises blame' that can then evade responsibility being attributed. We extend this analysis by suggesting that the dynamics associated with unintended consequences cannot be divested of responsibility, accountability or even, scrutiny. 'Explaining away' often deliberate and tactical decisions to advance particular political positions after a political agreement or settlement, fails to recognise the agency inherent in ongoing conflict processes. This paper suggests that even unambiguous legislation is a double-edged sword, and vulnerable to political compromise. What follows expands the analysis of the ways in which legislation designed to maintain and bolster peace, itself (re-) activates division, conflict and discord. Extending the discussion of responsibility forces a wider cognizance of the purposive action both driving and delivering peacebuilding legislation.

\section{Methodological Approach and Case Selection}

This paper is drawn from an extensive two-year study of cultural identity and spatial disputes in 'post-agreement' Northern Ireland. The study sought to explore the complex reality of living with and managing space in a society living with conflict. The impact 
of legislative peacebuilding and its implications for individuals, organisations, institutions formed an important strand of this research (Bollens 2000). The study was region wide and utilised field observation, witness seminars, focus groups, and individual semi structured interviews with key actors and organisations dealing with conflict and its management in Northern Ireland. This included community representatives, victim's groups, cultural organisations, local historical and cultural committees, public managers who are tasked with implementing equality legislation and those tasked with advisory roles on Northern Ireland's many public bodies and nongovernmental organisations. Data captured the experience of individuals and organisations engaged in or impacted by management of conflict at a community and at an organisational level.

The use of issue-based embedded cases allowed significant, high profile examples of spatial contestation to be explored in more detail. This paper details two of those cases, and the associated reflective, administrative and political processes around them. These high-profile disputes (the Union Flag Protest and the McCresh play park) were spatially based, directly associated with the legacy of conflict and occurred in conjunction with the implementation of peacebuilding legislation. In this they provided rich and contextually diverse examples of the phenomena under investigation. Data associated with these cases was drawn from and linked to the extensive general data collection process. This included three two-day residential workshops with community and voluntary sector participants in Derry/Londonderry, Belfast and Portadown; two witness seminars with thirty public managers who hold or have held policy implementation roles in a range of NI public sector environments; a series of facilitated discussions with community groups on issues around shared space and remembrance; and sixteen semi structured interviews with individuals engaged in the public or voluntary sector with a specific role in conflict management prevention.

Participation in the data collection process was secured through existing networks and snowball referral (Saunders 2016). Individuals were invited to engage in the way that that felt most comfortable and to suggest additional interviewees. Group events were held in neutral venues and facilitated by practiced researchers who had previous experience of data collection in societies of conflict. Witness seminars and interviews were recorded, transcribed and anonymised. Group events, particularly those involving 
community representatives were captured through contemporaneous note taking to allay confidentially concerns. Data was restructured to identify timescales, sectors, spatial zones, areas of controversy and inter-sectoral working. It was then coded to identify particular areas likely to provide theoretical insights and empirical interest.

\section{De-territorialising space in Northern Ireland: The 1998 Belfast Agreement}

The practices and processes of territorialisation have long been an integral part of the conflict in Northern Ireland (Shirlow 2006; Shirlow and Murtagh 2006; Murtagh and Shirlow 2012). Throughout the 'Troubles' warring ethno-nationalist groups engaged in their own distinct practices of territorial socialisation in order to reinforce localised territorial borders and gain support for contested macro-political campaigns. The battle for space was articulated through a wide range of practices including de jure and de facto segregation in housing and education (Borooah and Knox 2016), the establishment of no-go areas for security forces within Nationalist and Republican neighbourhoods (Dixon 2009), the symbolic claiming of territory through the painting of murals (Rolston 2010), the flying of flags (Bryan and Gillespie 2005), street-naming, memorial-building and parading (Graham and Whelan 2007; Cohen 2007), and the securitization and militarisation of borders through the deliberate construction of 'peacewalls' to segregate interface or enclave communities. These spatial articulations of inclusion and exclusion underpinned and reinforced the armed conflict and did not end with the inception of the peace process in 1993 and the negotiation of a political settlement five years later.

The Belfast/Good Friday Agreement was signed in April 1998, bringing almost thirty years of violence to an end. The diametrically opposed political and territorial ideologies of Irish Nationalism/Republicanism and Ulster/British Unionism/Loyalism, however, meant that 'resolving' the conflict would be an elusive objective. Instead, the Agreement sought to transform the nature of the conflict between the key stakeholders and address the constitutional question and the overarching sets of relationships between people on the island of Ireland and between Ireland and the UK. It stipulated that a power-sharing, devolved government would be introduced for the first time in the sub-state's almost 80-year history - a legislatively complicated, democratic compromise, reflecting rather than resolving the 'profound ambiguity' of a society caught between violent antagonism and the aspiration to reconciliation (Eyben et al 
1997). In doing so, it created a plethora of legislation operating at different governmental levels, aimed at promoting pluralism and mitigating tension and division between warring ethnic groups (Cousens and Cater 2001; Taylor 2006) and invested significantly in institutional change with a view to visibly altering the governmental and regulatory frameworks that surrounded the Northern Ireland body politic (Darby 2006; Horgan 2006).

One of the most significant and ambitious of these processes was the implementation of the Section 75 of the Northern Ireland Act. This duty was designed to intervene at a governmental level and impact both on intra organisational activities and the delivery of public services within Northern Ireland's stable, but still divided, society. Section 75 (1) of 1998 Act required designated public authorities to have 'due regard to promoting equality of opportunity' between persons of different religious belief, political opinion, racial group, age, marital status or sexual orientation, men and women generally, those with and without a disability and those with and without dependents. Section 75 (2) required these public authorities to have 'regard to the desirability of promoting good relations persons of different religious belief, political opinion or racial group'. The second duty was a clear attempt at introducing a legislative and organizational focus on peacebuilding, particularly with regard to how services were managed and the potentially differential impact of particular service delivery and policy interventions on sections of the community (Goldie 2012). There was a requirement to 'Equality Impact Assess' policies across the categories listed above. It was hoped that together these duties would underpin the transition to peace. As one former public manager noted:

Clearly equality and social justice were part and parcel of the Good Friday Agreement and the construction of section 75 was very intentional in terms of the framing of the two duties. When they were being introduced - they were described as being like legs on a stool. It was important that one didn't trump the other and both were necessary. But on reflection, what it has done over the last decade plus, is to put the two duties at war with one another. There are certain groups who will argue that, depending on the stance that government or an executive or organisation has taken, they are moving away from the equality duty and focusing on good relations duty (Interview with a former public manager, August 2016). 
As this quote implies, the implementation of legislation has been challenging for a number of reasons, not least the underlying nature of the conflict and the fact that the territorial aspirations of opposing groups in Northern Ireland were never fully resolved by the 1998 settlement. 'We still don't agree about the past, and not everyone considers the conflict over' (Community worker-workshop discussion, April 2015). This has had significant implications for territoriality and the meaning of borders and boundaries in a 'post-conflict' context. The Belfast Agreement did not, for example, deliver the political objectives of Irish Republicans who had hoped for the reunification of the island of Ireland (O'Leary 1999). For some Republicans who had participated in an armed campaign for independence against the British State, the Agreement represented something of a 'sell-out'. Republican leaders framed the Agreement as a 'new phase of the struggle' (Adams 1998 cited in McDowell 2007), insinuating that the struggle would continue, albeit by different means. Equally, the terms of the Agreement did not fully meet the long-time 'status quo' constitutional demands of the Unionist majority. Moving away from direct rule from Britain and into a power sharing government with Republicans, was for many a considerable challenge, while the proviso in the terms of the Agreement that a united Ireland would only be possible with a majority vote was an uncomfortable addition to the settlement.

Transforming conflict as opposed to resolving it in a zero-sum context has meant that while the constitutional question has been settled (at least until a majority decides otherwise), articulations of competing territorial ideologies have remained and public place continues to be the arena through which to continue the symbolic battle for hegemonic control (Goldie and Murphy 2015). Public places are therefore subject to the practices and processes of territorial socialisation and used as a war by other means in post-agreement struggles over identity, territory and belonging. In particular, we can pinpoint a set of embittered disputes surrounding place-making practices and the application of the Section 75 statutory duty which have had unintended consequences. Two are of particular interest, involving the symbolic territorialisation of public buildings through the flying of flags and the second through the naming of public recreational spaces. It is to these residual intercommunal tensions, and their outworking in the everyday contestation around territory, that the paper now turns. 


\section{Disempowering Unionism in Belfast City Centre? The Union Flag Protest}

'Equality is not the same as justice. Equality means what you want it to mean' (Interview with Public Manager, August 2016)

The 2012-2013 Union Flags protest created enormous division and political instability in cities, towns and villages across Northern Ireland (see Reilly and Trevisan 2015; Pennington and Lynch 2015). As far back as 2001, it had been argued by representatives of Sinn Féin (the largest Republican political party in Northern Ireland and the former political wing of the paramilitary group- the Irish Republican Army) that the flying of the British Union Flag from Belfast's City Hall, and the display of flags and memorabilia inside the City Hall itself, should be subject to an equality impact assessment (EQIA) under Section 75 regulations. They suggested that the flag and other artefacts were an exclusionary symbol and were not representative of everyone in Northern Irish society and should therefore, not be displayed daily on and in one of Belfast's most symbolic public buildings. City Hall was historically seen as a bastion of Unionism and a cold place for Nationalists and Republicans (Neill 1995). It was the venue in 1912 for the signing of the Solemn League and Covenant, a document which pledged the Ulster Unionists' commitment to the Union with Britain amid the Home Rule Crisis in Ireland. When it became apparent that a Home Rule government would take effect as a response to the 'Irish Question', the leaders of Ulster Unionism rallied their supporters, mobilising hundreds of thousands of Unionists to participate in a day of protest activities in Belfast's city centre. The Ulster Covenant was signed by over half a million people on 'Ulster Day' in City Hall (28 $8^{\text {th }}$ September) conflating the defiance of Unionism irrevocably with the building itself. City Hall quickly became a symbol of Unionist resistance, the epicentre of a carefully choreographed political campaign to protect the Union with Britain (Guelke 2014). The signing of the Covent in City Hall can be understood as one of the first acts of territorial socialisation to have taken place in the centre of a city that would become increasingly polarised and segregated over the years.

Nagle (2009), writing about spatial power dynamics within Belfast, suggests that access to the city centre for both ethno-nationalist groups has traditionally been indicative of the broader power relations within Northern Irish society. For Unionists whom have been 'historically the dominant ethno-nationalist group', the city centre was, as he 
suggests, "their exclusive domain for civic occasions. The performance of Unionist commemorative and political parades in the city centre concentrated on making visible their power/dominance over the state's economic or political institutions' (Nagle 2009, 328). This almost hegemonic ownership over the heart of the city (one of the few nonresidential areas) continued until the inception of the peace process. Access to the city that they had been excluded from became embedded within the Nationalist and Republican struggle, and became an integral part of policy initiatives and peacebuilding legislation surrounding shared space in peacetime (Nagle 2009).

The flying of the Union Flag on City Hall first became an issue shortly after the signing of the Agreement in 1998. In a Council meeting in May 2004, the council took the political decision not to introduce any change to its policy to fly the flag 365 days a year. However, in 2011 the debate reignited, following local government elections in which Sinn Féin became the largest party on Belfast City Council. An original investigation into internal and external symbols resulted in two EQIA's - with two different outcomes. The internal process on memorabilia was a complex but eventually positive exercise. The external EQIA which was identical in scope concluded that the permanent position of the Flag 'give rise to an adverse impact on residents, visitors and employees with a Catholic and/or Nationalist community background in terms of their expectation that the Council will have regard to the desirability of promoting good relations in the implementation of its policies' (EQIA, BCC, 2012). Feeding into an already politically charged local environment, the controversy was not simply about the flying of flags on public buildings. For Unionist and Loyalist protestors, it was indicative both of a lack of respect for their culture and identity. 'Loosing' City Hall was indicative of a symbolic battle with far reaching implications. The leader of the Orange Lodge reacted strongly claiming that 'Republicans are engaged in a cultural war to erode all symbols of Britishness'. As one protestor remarked 'It's not just the flag. They want to take everything British away' (McDonald 2013). A senior public manager in Belfast, reflecting on this process with its internal and external dimensions commented; 'The flag and the memorabilia, we got the two EQIA's done at the same time. The equality complaint came in but we split them - flag outside and memorabilia to be a separate EQIA, the flag one became very transactional - a binary outcome' (Interview with public manager, August 2016). 
For disaffected Unionists and Loyalists, losing the right to fly the flag over a building they felt was synonymous with their culture and heritage was indicative of a much deeper feeling of disempowerment within the new political dispensation and landscapes of 'post-conflict' Northern Ireland (see Southern 2007; McAuley 2016). Additionally, for some Unionists it appeared to confirm their fears of the continued territorialisation of 'their' space by Republicans. In the weeks before a scheduled Council vote on the Flag, Unionist political parties (the Democratic Unionist Party and the Ulster Unionist Party) distributed over 40,000 leaflets across Belfast urging supporters to take action and vocalise their political opinion. The leaflet showed two images of City Hall, one with the Union Flag and one without, and employed the government's political rhetoric of a shared future as a strap line to highlight the perceived injustice of the vote. The leaflet read 'A shared future: for who?' insinuating that the legislation surrounding a parity of esteem and sharing space disproportionately benefits one section of the community (and in doing to undermines the other). The leaflet stated that 'the Union flag is the flag of our country and is causing no offence to anyone... we can't let them make Belfast a cold house for anyone'.

Political representatives met on the $3^{\text {rd }}$ December and a majority voted in favour of limiting the days on which the Union Flag flies on Northern Ireland's public buildings. The result occasioned a plethora of protests, some of which were violent and involved harm to people and property. Amid the significant street disturbances, business leaders reported multimillion pound loses, city centre shops closed and police warned of a lasting negative impact on community relations within the city and beyond. The protests quickly gained momentum throughout Northern Ireland, extending to cities, villages and towns, galvanising a population in an unprecedented outpouring of anger. Many politicians were keen to write the protests off as a sectarian minority. Gerry Adams (2013), President of Sinn Féin, writing on his blog about the Flags protest attributed the trouble to a minority dissatisfied with the peace process and incapable of accepting the concept of a parity of esteem: 'Belfast is no longer a Unionist city. It is a shared city'. ...Reflecting on the 'old Belfast' he wrote 'Tens of thousands of nationalists were denied the vote...They were denied jobs and housing. The Irish language, music and culture were marginalised, and the political representatives of northern nationalists had no influence or power. The northern state was an Orange state. ...For Unionism, the Orange state gave them a sense of belonging, of cohesion and 
superiority. The peace process and the Good Friday Agreement have changed all that...Equality is not about one side dominating the other'.

Very clearly, the use of Section 75 over the flying of flags in Northern Ireland has had unintended consequences that have reverberated far beyond questions of the use of symbols in shared public spaces. Turner (2014) suggests that the flag protest is indicative of a broader issue about hegemonic voices and control in post-agreement society. She suggests that the language of transition plays an important role in articulating influence and competency in an unstable political landscape. Republicans, Turner argues, have harnessed this language in ways that have increased their efficacy and political strength: 'This strategy has been adopted with devastating effectiveness by the Republican political leadership. Those who have been unwilling or unable to adopt the language of transition remain marginalised and voiceless, far removed from political power or influence' (Turner 2014). In this instance, Loyalist protesters have become the powerless, unable to articulate their voice and control a space once regarded as solely the preserve of Unionism. As Adams (2013) suggests 'The north is not as British as Finchley-as Margaret Thatcher once suggested'. Adams' tone in this statement reveals a sense of victory, a minor point scored in a zero-sum political situation where the smallest of victories represents another facet of the struggle.

\section{Political point scoring and the commemoration of conflict}

'Our culture is adversarial' (Interview with public manager, August 2016).

Section 75 has not only been used to contest the flying of national flags on key public buildings, but has been employed in a number of battles surrounding dealing with Northern Ireland's contested past. The commemoration of conflict, both recent and more distant, is not just about acknowledging loss and sacrifice. It can be interpreted as an inherently political and territorial act, and has been at the core of a fractious public discourse surrounding the legislation of space in a post-agreement context. Physical representations of the past, manifesting in memorials, plaques, murals and re-naming initiatives have been crucially important to many groups and organisations, and have gained momentum since the signing of the 1998 Agreement, as such groups embarked upon a process of reifying their narratives of the past onto the contested streetscapes of the 'new' Northern Ireland. With no agreed or shared understanding of the origins of 
conflict and the emergence of competing claims to hegemonic victimhood, representations of the past became vehicles through which to legitimise violence and attribute blame. Furthermore, commemoration has been used in part to continue the demarcation of territorial boundaries and promote group cohesion in a rapidly changing and uncertain political environment (McDowell and Braniff 2014).

The commemoration of former paramilitaries in public space has been particularly controversial (see McDowell 2007; Brown and Grant 2016). One of the most highprofile disputes concerns the renaming of a public recreational space. In 2014, a heated debate broke out surrounding the renaming of a public children's play park, after a former IRA combatant. Newry and Mourne District Council (a local government body) was subject to an investigation by the Equality Commission over a controversial decision to name a children's play park in the city of Newry after a prominent Republican paramilitary, Raymond McCreesh, who had died on hunger strike in the Maze Prison in 1981 (The Newry Times, 10 April 2014). He had died agitating for political statue alongside nine other men, gaining an important role in Republican hagiography (English 2004). The grounds for the Equality Commission investigation lay in Paragraph 11 of Schedule 9 of the Northern Ireland Act, which relates to upholding good relations: specifically, it gives the Equality Commission the power to investigate cases 'where a public authority may have failed to comply with its Equality scheme' - laid out in Section 75 (see above). The play park, owned by Newry District Council, had previously been called St Patrick's Play Park but was renamed using bilingual signs (in both English and Irish - a further outcome of peacebuilding legislation to promote equality) as the Raymond McCreesh Park following a request by the 1981 Hunger Strike Commemoration Committee in 2001 as part of the twentieth anniversary commemorations. These particular commemorations were acutely ambitious with previously unprecedented scope and reach. Across Northern Ireland, a plethora of murals, memorials, plaques and renaming activities commemorated an important struggle for the reunification of Ireland that the Republican leadership had, at least on paper, ended. Commemorating the $20^{\text {th }}$ anniversary was one way in which the leadership could calm anxiety about the levels of change and reassure supporters that the struggle that they had supported for so long had simply changed form and was not in vain (McDowell 2007). The political landscape at that particular point in time, was very much in flux. The new political dispensation was plagued with teething 
problems and policymakers and public managers were struggling to implement a raft of peacebuilding legislation in an uncertain climate. The local Council in Newry and Mourne, while responsible for the renaming, had failed to complete a formal Equality Impact Assessment as required by Section 75 of the 1998 Act, although it did solicit views from the general public. The Equality Commission flagged the name of the park in 2008 citing Section 75 following a complaint from Unionists that a former paramilitary should not be commemorated in a children's recreational space. Following the solicitation of views from members of the community living in close proximity to the park, the Council voted to keep the name in December 2012, 22 votes (comprising 20 Republican/Nationalist political representatives and two independents) to five (comprising Unionist politicians). Unionist politicians attacked Republican and Nationalist politicians for demonstrating in this instance 'how pious their lectures to Unionists on equality and good relations really are' (Irwin 2012).

The controversy over the playpark continued and in 2015 after sustained pressure, Newry and Mourne Council had to reopen the renaming debate. The Equality Commission asked the Council to adhere to Section 75 and scheduled yet another vote for March 2015. After a lengthy public debate, the Council voted on retaining the name, a decision which actioned further criticism, polarising opinion and entrenching division. Republican politicians defended the renaming decision, stating that it had been a democratic decision: 'The people have spoken in 2001 when they named the park, and again in 2008 when it was investigated by the Council, and yet again in 2015. People are trying to ignore a democratic decision' (Kimmins 2015). Other Republican figures justified their decision, suggesting that 'The many that admire freedom fighter Raymond McCreesh have as much right to remember him in the ways that those who admire Unionist peers, British Knights and British Kings' (Brady 2015). Another Sinn Féin representative argued the case in a debate in Stormont stating that 'The courage and resolve of Raymond McCreesh and his nine comrades is held in the highest regard in the Republican and nationalist community, Indeed, I have heard many others acknowledge their courage and integrity without endorsing their political philosophy. So people cannot and should not be surprised that this manifests itself in places, organisations and events being named and held in their memory' (McCartney 2015). 
Unionists reacted angrily to the decision, rejecting the Commission's decision. UUP representative Taylor (2015) stated 'We will be exploring every avenue that we have at our disposal to ensure that we get this decision changed'. While some suggested that the park's name was 'grotesquely offensive to one side of the community' (Reilly 2015), others suggested it had serious implications for peacebuilding, arguing that Northern Ireland could not seriously 'move forward if shared space is named after those guilty of perpetrating terrorist actions' (Kennedy 2015). After a brief hiatus, the controversy reignited once more in 2016 whenever the mother of a man killed by the IRA took the Equality Commission's decision to the High Court to request a review. Dr Michael Wardlow, the Chief Commissioner of the Equality Commission, said 'When we made our final decision, the Commission expressed its disappointment that the opportunity was not taken up to find a name for the playpark that would have more positive resonances with all those in the council and that would be more conducive to good relations between the communities' (Morris 2015). A senior policy professional working in Equality was less tactful 'The McCresh playpark was an outrageous example of supine public management in the way it has handled...A classic example of public managers not being able to separate themselves from political expediency' (Interview with Senior Equality Manager, 2016).

The renaming debacle is a particularly useful example of how territorial socialisation works within ethno-nationalist groups. A playpark is, in many ways, an everyday leisure space for a community. It is a 'safe space' that is not only critical for fostering developmental milestones and encouraging outside play, but as a forum for social interaction. Providing shared spaces for social interaction in order to foster better crosscommunity relationships has been a key priority for policymakers in the wake of the Agreement (CRU 2005; Graham and Nash 2006). Yet the naming of the playpark in a public place after a contentious political figure adds yet another layer of significance to an otherwise seemingly 'apolitical' space. Semantics are critically important within the context of territorialisation (Tuan 1991). It is widely accepted that (re-) naming is an inherently political process used to territorialise space and embed specific values among the social fabric of communities (see Azarahyu 1996, 2011; Alderman 2003). Naming evokes a narrative that has an emotive or symbolic meaning, serving to dichotomously include and exclude. As Newman and Paasi $(1998,198)$ note: 'The construction of boundaries at all scales take place through narrativity'. This particular 
example is significant for a number of reasons: firstly, it helps to capture the state of cross-community relationships between elected representatives responsible for naming public spaces in a post-agreement context. In this context, key stakeholders can manipulate controversies to their advantage and secure token victories over their counterparts. Secondly, renaming a playpark after an important Republican figure ensures the transgenerational transfer of an important narrative within Republicanism to children who are increasingly far removed from the Northern Ireland conflict - an important aspect of processes of territorial socialisation. Thirdly, the broader spatial resonance is significant: the naming of a park for one section of a community despite a lack of consensus sends a specific message to outsiders that this playpark is exclusionary not inclusionary-it is demarcated for children from a particular ethnonationalist group. This example serves as a reminder of the potent effects peacebuilding legislation can have in a society where the territorialisation of space remains critically important. "It always seemed to me that Section 752 was an add-on and it didn't have the weight of Section 75 (1), and particularly because you had the EC enforcing section 75 (1), Politically SF were very keen on Equality S75 (1) - they have never been keen on Section 75(2). They didn't fight a war over an equality agenda but you'd now think they did" (Interview with public manager 2016).

\section{Peacebuilding, territorial socialisation and unintended consequences}

Peace is rarely straightforward: spoiler violence, the monopolisation of resources and the destruction of trust and networks remain key threats to embedding stability (Paffenholz 2008). Such threats are well-acknowledged in debates and often pose significant challenges to the processes of 'demobilisation, demilitarisation and reintegration' (DDR). Yet, less commonly understood is the threat to peace emerging from the very source that is intended to build peace. A key contribution offered by this exploration of territorial socialisation in zero-sum contexts and peacebuilding legislation reveals that threats to peace are often more significant than first acknowledged or commonly understood. We have illustrated that when the politics of space, memory and identity collide in a zero-sum political situation, even after a political agreement to build peace, the very legislation designed to mediate intercommunal tensions instead becomes the process through which conflict can be continued. Our two cases illustrate starkly the significance of both legislative implementation processes and the persistence of division and conflict. Navigating the 
memory of recent violence in conjunction with contemporary identity based clashes creates a potent environment in which to both legislate and manage legislative interventions. Within a more acute understanding of both potential, unwelcome outcomes and the difficulties of implementation space in particular is at risk of remaining contested. In cases like these, when peacebuilding legislation has the potential to exacerbate rather than ameliorate conflict, it is importantly to carefully track and trace conflict reoccurrence and the critical, vulnerable junctures that exist within these processes.

The difficulties embodied in the McCreesh and Flag controversies are illustrative of the types of challenges facing policymakers in a post-agreement context. They are also indicative of a society where territorial socialisation and political point scoring set against a zero-sum political environment intrinsically matter. These two examples point to the continued importance of territorial socialisation in a society that places a premium on demarcating public places, the significance of skilled and careful implementation and the double edged sword of legislative interventions. Place-making activities can be used to reinforce and contest ownership of space and reactivate tribal spatial politics. Peacebuilding legislation itself become 'weaponised' and employed by warring groups to gain political capital. It has become a symbolic theatre, continuing the conflict by other means.

In zero-sum contexts, responsibility for driving peace forward rests largely, but not only, with the political elites. Legislation designed by policy-makers to build peace is particularly vulnerable in an implementation vacuum without experienced and skilled public managers. As one public manager commented 'people can bend over backwards to be so even handed that they are detached-treating people as if they are the same is neither a measure or the mission of equality' (Interview with public manager, May 2016). As we see above, even with skilled management, sometimes the potency and 'priming' (Cornelissen and Werner, 2014) of old political constructs is too powerful to be managed in the public sphere. This is a central tenet of the argument evidenced and advanced here: the complexity and potential paradox of peacebuilding at a legislative level. Section 75 is a form of legislation that has been exposed to the socio-political decision-making process and it now sits at the forefront of the politics of contention of territorial socialisation: working to produce outcomes unanticipated in its drafting. 
Through the dispute around symbols and names to contest minority and equal rights demands, at a local governance level, the commodification of peacebuilding legislation around Section 75 is exposed. This raises significant implications for how policy is designed and risk-assessed in zero-sum contexts, particularly around the local applicability of international norms and conventional thinking about linear, pro social legislative activity in a zero-sum context. It also brings into stark relief the importance of implementation and the reality that legislating for better relations is not enough.

Peacebuilding through international norms of human rights is problematic when confronting the territorialisation of space. The argument and evidence explored in this paper engages critically with contemporary policy implementation frameworks and suggests that unintended consequences are facilitated by international global norms as advocated by supra-international bodies such as the United Nations Charter for Human Rights and the European Charter for Human Rights. Leveraging the concepts and debates around unintended consequences to examine peacebuilding legislation reveals the under-examined nature of much of what is assumed to be working towards peaceful negotiation in transitional contexts. Looking carefully at the implementation of legislation in contested spaces, unhinges contemporary debates that assumes the intentions of legislating for peace in contested spaces are typically realised. As the Northern Ireland examples suggest, global norms and accompanying legislation face the reality of monopolisation and manipulation by those seeking to challenge and navigate emergent peace processes to shore up their own or their communities' interests, or by implementers without the skills, knowledge or organisational leverage to lobby for different outcomes. An understanding of the critical nature of conflict tenacity within groups that are technically at peace, but still antagonistic and seeking opportunities to pursue hostility, must be understood within the context of peacebuilding legislation in the same way it is understood at a micro community or a macro political level.

Whilst invaluable to the study of unintended consequences and legislation, Northern Ireland is not unique or unusual, as contention and circular challenges emerge postagreement. Post-agreement societies habitually struggle with the unintended consequences of legislation designed to embolden and protect peace processes (Cousens and Cater 2001; Braniff 2012). This is a wider reflection of international 
norms and a raft of legislative endeavours drawn up by the Organisation for Security and Cooperation in Europe (OSCE 1992); the Council of Europe (1995), as well as the United Nations $(1951 ; 1976 ; 1993)$. Protecting minority rights after genocide, war and conflict is embodied in the United Nations Convention on the Prevention and Punishment of the Crime of Genocide (1951), as well as the International Covenant on Civil and Political Rights (1976: Art. 27).

In the countries emerging from the violence of the dissolution of Yugoslavia, we can see a very direct comparison with Northern Ireland's Section 75 Legislation. For instance, in 2002 Croatian national law incorporated legislation to protect the rights of citizens: the 'Constitutional Law on the Rights of National Minorities' has been utilised as a means of propagating conflict, whilst advocating building peace. Article 7 safeguards cultural autonomy and religious practice and 'protects the right of national minorities to freely use their language and script, privately and publically, including the right to display and access signs, inscriptions and other information', with a $30 \%$ margin stipulated. This law has worked in dichotomous ways: protecting minority rights but a catalyst for destabilising intercommunal relations and deepening tensions, in places like the deeply divided town of Vukovar on the Croatia/Serbia border. When, in 2011 , the Serb population reached the baseline limit of $30 \%$ of the population and called upon the legislation to advance minority rights, this triggered deep and regional protests and intercommunal discord, akin to other forms of spatial and symbolic politics (Fischer and Simic 2015; McDowell and Braniff 2014). Far from managing or resolving intercommunal tensions and building peaceful intercommunal relations, this legislative act performed as a source of contestation in both local and national Croatian spatial, social and political life. The Balkan context demonstrates that there is significant merit in blending the spatial, political, public sector and legislative analyses of attempts to move societies out of conflict in a way that limits the impacts of unintended consequences.

\section{Conclusion}

Peacebuilding possesses are imbued with understandings of the conflict that has gone before. Symbolic debates on difficult pasts often become most acute in relation to issues of territory and public space. Within the Northern Ireland case studies discussed here, 
equality legislation has both enacted and reactivated territorial contestation. Legislation designed to build better relations, is increasingly part of the conflict process itself. Far from managing or resolving intercommunal tensions, it has be utilised as a source of contestation in the spatial, social and political life of Northern Ireland. The examples outlined above, indicate that significant symbolic battles remain regarding how the past, present and future understandings of identity and conflict are negotiated. Contestation around naming of public play parks and symbolic flying of national flags demonstrate that Section 75 is a point of contention, rather than a point of peacebuilding. In turn, the cases show that a law designed to protect minority and enhance equal rights and a law that speaks directly to the realm of identity within a zero-sum conflict can serve to reinforce narratives of attachment to territory rather than accelerate de-territorialisation in post-agreement contexts.

This paper has explored the unintended consequences of the implementation of overt peacebuilding legislation and its role in reinforcing separation and the territorialisation of space within the context of a divided society. In doing so, it contributes to and extends the growing body of work on peace research that advocates a more subtle appraisal of the relationship between space and peacebuilding (Megoran 2011; McConnell et al, 2014). The Northern Ireland case studies illustrate the inherent difficulty in legislating for peace within space, and highlight the persistent nature of residual conflict after ethno political violent conflict and war, reaffirming Koopman's (2017) assertion that peace and conflict co-exist: inexorably bound together; existing within the other. As one interviewee noted 'Northern Ireland is a society emerging from violence but still living with conflict, with difference and difference of opinion' (Interview with a public manager, August 2016). As we have seen here, the temporal and territorial dimensions of peacebuilding and legislative interventions are clearly complex and non-liner in their outcomes. They differ across space, time and scale (Ross 2012; Shimada 2014). The Northern Ireland case and its examples illustrate acutely how legislation, which was explicitly designed to foster better relations can be used, particularly within the realm of space and sharing, as another weapon in societies no longer at war, but struggling to be at peace.

\section{References}


Adams G (2013) There's no going back for Belfast: Sectarianism must be ended http://leargas.blogspot.co.uk/search?q=union+flag 12 January 2013, accessed 10 September 2016.

Alderman DH (2003) Street names and the scaling of memory: The politics of commemorating Martin Luther King, Jr within the African American community. Area 35(2): 163-173.

Azaryahu M (1996) The power of commemorative street names. Environment and Planning D: Society and Space 14 (3): 311-330.

Azaryahu M (2011) The critical turn and beyond: the case of commemorative street naming. ACME: An International E-journal for critical geographies 10 (1): 28-33.

Baert P (1991) Unintended consequences: a typology and examples. International Sociology 6 (2): 201-210.

Basch, L., Schiller, N.G. and Blanc, C.S. eds (2003) Nations unbound: Transnational projects, postcolonial predicaments, and deterritorialized nation-states. Routledge.

Bekoe D (2016) Implementing peace agreements: lessons from Mozambique, Angola, and Liberia. New York, Springer.

Bell C and O'Rourke C (2010) Peace agreements or pieces of paper? The impact of UNSC Resolution 1325 on peace processes and their agreements. International and Comparative Law Quarterly 59: 941-980.

Billig M (1995) Banal nationalism. London, Sage.

Björkdahl A and Buckley-Zistel S eds. (2016) Spatialising Peace and Conflict: Mapping the Production of Places, Sites and Scales of Violence. Springer.

Blackman R (2006) A wall in Palestine. Picador: New York 
Bollens SA (2000) On Narrow Ground: Urban Policy and Conflict in Jerusalem and Belfast, Albany, New York Press.

Bollens SA (2012) City and soul in divided societies. Routledge.

Borooah VK and Knox C (2013) The contribution of 'shared education' to CatholicProtestant reconciliation in Northern Ireland: a third way? British Education Research Journal 39: 925-946

Boudon R (1977) Education and social mobility: a structural model. Power and ideology in education, 186-196.

Braniff M (2012) Integrating the Balkans: Conflict Resolution and European Union Expansion, I.B. Tauris, London and New York.

Brickell K (2015) Towards intimate geographies of peace? Local reconciliation of domestic violence in Cambodia. Transactions: Institute of British Geography, 40: 321333.

Brown K and Grant A (2016) A Lens Over Conflicted Memory: Surveying 'Troubles' Commemoration in Northern Ireland. Irish Political Studies 31(1): 139-162.

Bryan D and Gillespie G (2005) Transforming conflict: flags and emblems. Institute of Irish Studies, Queen's University Belfast.

Cousens E and Cater CK (2001) Implementing the Dayton Accords. London, Lynne Reiner.

Calame J and Charlesworth E (2011) Divided Cities: Belfast, Beirut, Jerusalem, Mostar, and Nicosia. University of Pennsylvania Press.

Chandler DC (2006) Empire in denial: the politics of state-building. Pluto. 
Cohen S (2007) Winning while losing: The Apprentice Boys of Derry walk their beat. Political Geography 26(8): 951-967.

Cornelissen J P and Werner M D (2014) Putting Framing in Perspective: A Review of Framing and Frame Analysis across the Management and Organizational Literature. The Academy of Management Annals, 8, 181-235.

CRU (2005) A Shared Future-Improving Good Relations in Northern Ireland. The policy and Strategic Framework for Good relations in Northern Ireland (21 March), Belfast, Community Relations Unit, OFMDFM.

Cousens E and Cater C K (2001) Implementing the Dayton Accords. London: Lynne Reiner.

Daase C and Friesendorf C (2010) Rethinking Security Governance: The problem of unintended consequences. London, Routledge.

Darby J P (2006) Violence and reconstruction. University of Notre Dame Press.

Diehl PF (1999) Territory and International Conflict: An Overview. A Road Map to War: Territorial Dimensions of International Conflict.

Dixon P (2009) 'Hearts and Minds'? British counter-insurgency strategy in Northern Ireland. The Journal of Strategic Studies, 32(3):445-474.

Duchacek I D (1970) Comparative federalism. New York: Holt, Rinehart and Wilson.

Elster J (1990) Norms of revenge. Ethics, 100 (4): 862-885.

Eyben, K, Morrow, D, and Wilson D (1997) A Worthwhile Venture? Practically Investigating in Equity, Diversity and Interdependence in Northern Ireland. University of Ulster. 
Fagan A and Sircar I (2015) Europeanisation and multi-level environmental governance in a post-conflict context: the gradual development of environmental impact assessment processes in Bosnia-Herzegovina. Environment and Planning C: Government and Policy October 33: 919-934

Fischer F (2003) Reframing public policy: Discursive politics and deliberative practices. London, Oxford University Press.

Fischer M and Simic O (2015) Transitional Justice and Reconciliation: Lessons from the Balkans. Oxon: Routledge.

Flint C (Ed) (2005) The geography of war and peace: from death camps to diplomats. Oxford University Press on Demand.

Gebrewold B (2009) Anatomy of violence: Understanding the systems of conflict and violence in Africa. Ashgate Publishing, Ltd.

Goldie R (2012) Problem, Process and Product: Implementing Key Reforms in Local Government in Northern Ireland since the Belfast Agreement. Local Government Studies, 38, 525-537.

Goldie R and Murphy J (2015) Belfast beyond violence: Flagging up a challenge to local government? Local Government Studies, 41, 470-488.

Graham B and Nash C (2006) A shared future: territoriality, pluralism and public policy in Northern Ireland. Political Geography 25(3): 253-278

Graham, B and Whelan Y (2007) The legacies of the dead: commemorating the Troubles in Northern Ireland. Environment and planning D: society and space, 25(3): 476-495.

Grosby, S (1995) “Territoriality: The Transcendental, Primordial Feature of Modern Societies," Nations and Nationalism 1, no. 2 
Guelke A (2014) Northern Ireland's flags crisis and the enduring legacy of the settlernative divide. Nationalism and Ethnic Politics, 20(1): 133-151.

Hess M and Korf B (2014) Tamil diaspora and the political spaces of second-generation activism in Switzerland. Global Networks, 14(4): 419-437.

Horgan G (2006) Devolution, direct rule and neo-liberal reconstruction in Northern Ireland. Critical Social Policy 26: 656-668

Irwin W (2012) Newry playpark will remain named after hunger striker McCreesh. BBC News 5 September http://www.bbc.co.uk/news/uk-northern-ireland-20594280 accessed 6 June 2016.

Jansen S (2002) The Violence of Memories: Local narratives of the past after ethnic cleansing in Croatia, Rethinking History, 6 (1): 77-93

Johnson N (1995) Cast in stone: monuments, geography, and nationalism." Environment and planning D: society and space 13 (1): 51-65.

Kennedy D (2015) Raymond McCreesh will never be anything other than a terroristKennedy, Ulster Unionist Party News $3^{\text {rd }}$ March 2015 available at http://uup.org/news/3418/Raymond-McCreesh-will-never-be-anything-other-than-aterrorist-Kennedy\#.WZ2hbSiGPIU accessed 10 October 2016.

Kimmins L (2015) 'It's time to move on from the McCreesh issue'. Newry Times $29^{\text {th }}$ May.

Klem B (2014) The political geography of war's end: Territorialisation, circulation and moral anxiety in Trincomalee, Sri Lanka. Political Geography 38: 33-45.

Kobayashi, A. (2009). Introduction: Geographies of peace and armed conflict: Introduction. Annals of the Association of American Geographers 99, pp 819-1059.

Koopman S (2011) Let's take peace to pieces Political Geography 30 193-94. 
Koopman, S. 2017. Peace. The International Encyclopedia of Geography. 1-4.

Lekha Sriram C (2007) Justice as Peace? Liberal Peacebuilding and Strategies of Transitional Justice, Global Society, 21 (4): 579-591.

Loncar J (2016) State-building and local resistance in Kosovo: Minority exclusion through inclusive legislation, Communist and Post-communist Studies (in press).

Loyd J M (2012) Geographies of peace and antiviolence. Geography Compass, 6(8), 477-489.

Maney, G.M., Ibrahim, I., Higgins, G.I. and Herzog, H. (2006) The past's promise: Lessons from peace processes in Northern Ireland and the Middle East. Journal of Peace Research 43(2): 181-200.

MacGinty R and Richmond O (2013) The local turn in peace building: a critical agenda for peace, Third World Quarterly 34 (5) pp. 763-783

MacGinty R and Richmond O (2007) Myth or Reality: Opposing Views on the Libral Peace and Post-war Reconstruction. Global Society 21 (4): 491-497.

Mamadouh, Virginie (2005) “Geography and War, Geographers and Peace.” In The Geography of War and Peace: From Death Camps to Diplomats. Edited by Colin Flint, 26-60. Oxford and New York: Oxford University Press.

McAuley J (2016) Memory and belonging in Ulster Loyalist identity Irish Political Studies 31 (1): 122-138.

McCartney R (2015) McCreesh Park, Private Members' Business-in the Northern Ireland Assembly $3^{\text {rd }}$ March https://www.theyworkforyou.com/ni/?id=2015-03-03.6.1 accessed 12 September 2016 
McConnell, F, Megoran, N and Williams, P eds. (2014) Geographies of Peace: Tauris: London.

McDonald, H. (2013) Belfast: 'It's not just the flag. They want to take everything British away', The Guardian 12 January.

McDowell S (2007) Armalite, the ballot box and memorialization: Sinn Féin and the state in post-conflict Northern Ireland. The round table, 96(393):.725-738.

McDowell S and Braniff M (2014) Commemoration as conflict: space, memory and identity in peace processes. London: Palgrave.

Megoran N 2011 War and peace? An agenda for peace research and practice in geography. Political Geography 30: 178-89.

Megoran N, Williams P and McConnell F 2014 Geographies of peace, geographies for peace in McConnell F, Megoran N and Williams P eds Geographies of peace IB Tauris, London 250-60.

Merton RK (1936) The unanticipated consequences of purposive social action. American sociological review 1(6): 894-904.

Moore A (2016) Ethno-Territoriality and Ethnic Conflict, Geographical Review 106: 92-108.

Morris A (2015) Equality Commission backtracks on 'Raymond McCreesh park', Irish Times 02 July.

Morrissey M. and Gaffikin F (2006) Planning for Peace in Contested Space. International Journal of Urban and Regional Research 30: 873-893

Murtagh B and Shirlow P (2012) Devolution and the Politics of Development in Northern Ireland. Environment and Planning C: Government and Policy 30 (1): 46-61 
Nagle J (2009) Sites of centrality and segregation: Lefebvre in Belfast, a 'divded city'. Antipode: A Radical Journal of Geography 41 (2): 326-347.

Neill W J (1995) Lipstick on the gorilla? Conflict management, urban development and image-making in Belfast. In Neill, WJ, Fitzsimmons, D. and Murtagh, B. (eds) Reimagining the Pariah City: urban development in Belfast and Detroit. Avebury: Aldershot, pp.

Newman D (1999) Real spaces, symbolic spaces: Interrelated notions of territory in the Arab-Israeli conflict. In Geographies of the Mind, edited by Paul Francis Diehl, Nashville and New York: Vanderbilt University Press, pp 3-36.

Newman D (2006) The lines that continue to separate us: borders in our borderless world. Progress in Human geography 30 (2): 143-161.

Newman, D and Paasi, A. (1998) Fences and neighbours in the postmodern world: boundary narratives in political geography. Progress in human geography 22(2): 186207.

O'Leary B (1999) The nature of the Agreement. Fordham Journal of International Law, 22 (4): 162-67.

Paasi A (1999) Boundaries as social practice and discourse: The Finnish-Russian border. Regional studies, 33(7), 669-680.

Parsons N and Salter M (2008) Israeli biopolitics: closure, territorialisation and governmentality in the occupied Palestinian territories, Geopolitics, 13 (4): 701-723

Paffenholz T (2008) Exploring opportunities and obstacles for a constructive role of social capital in peacebuilding. In Cox M ed Social Capital and Peace-Building: Creating and resolving conflict with trust and social networks: 186-194. 
Pennington K and Lynch, O (2015) Counterterrorism, Community Policing and the Flags Protests: An Examination of Police Perceptions of Northern Ireland's Operation Dulcet. Studies in Conflict \& Terrorism, 38 (7): 543-559.

Pugh M (2010) Welfare in war-torn societies: nemesis of the liberal peace?. In Palgrave Advances in Peacebuilding (pp. 262-278). Palgrave Macmillan UK.

Pugh, M., Cooper, N. and Turner, M. eds. (2016) Whose peace? Critical perspectives on the political economy of peacebuilding. Springer.

Pullan W and Gwiazda M (2009) 'City of David': Urban Design and Frontier Heritage. Jerusalem Quarterly 39 (2).

Reilly 2015 H (2015) Raymond McCreesh Park: Newry Sinn Féin Councillors reject fresh vote, BBC News $2^{\text {nd }}$ March http://www.bbc.co.uk/news/uk-northern-ireland$\underline{31703859}$ accessed 6 June 2016.

Reilly P and Trevisan F (2015) Researching protest on Facebook: developing an ethical stance for the study of Northern Irish flag protest pages. Information, Communication \& Society, 19(3): 419-435.

Rhodes RA (1997) From marketization to diplomacy: It's the mix that matters. Public Policy and Administration, 12(2): 31-50.

Richmond, O (2014) Foreword, In McConnell F, Megoran N and Williams P eds Geographies of peace IB Tauris, London, pp xiv-xvii.

Rolston B (2010) Trying to reach the future through the past. Crime Media Culture 6 (3): 285-307.

Ross, A. (2011). Geographies of war and the putative peace. Political Geography, 30(4), 197-199.

Ryan S (2016) The transformation of intercommunal conflict. London: Routledge. 
Saunders M (2016) Reporting and Justifying the Number of Interview Participants in Organization and Workplace Research. British Journal of Management, 27, 836-852.

Shimada LD (2014) Transforming 'The Troubles': cultural geographies of peacebuilding in Northern Ireland. In McConnell, F, Megoran, N and Williams, P. Geographies of Peace: Tauris: London. pp.151-165.

Shirlow P (2006) Belfast: the 'post-conflict' city. Space and Polity 10(2): 99-107.

Shirlow P and Murtagh B (2006) Belfast, Segregation and Violence in the City. Chicago: Chicago University Press.

Southern N (2007) Protestant alienation in Northern Ireland: A politica, cultural and geographic examination Journal of Ethic and Migration Studies 33 (1): 159-180.

Sriram C (2016) Peace as governance: Power-sharing, armed groups and contemporary peace negotiations. London: Springer.

Svensson I (2013) Research on bias in mediation: policy implications. Penn Street Journal Law and International Affairs 2 (1): 17-26.

Talberg J (2002) Paths to compliance: Enforcement, management, and the European Union. International Organization 56 (3): 609-643.

Tarrow S (2001) Transnational politics: contention and institutions in international politics. Annual Review of Political Science 4 (1): 1-20.

Taylor R (2006) The Belfast Agreement and the Politics of Consociationalism: A Critique. Political Quarterly 77 (2): 217-226.

Till K (2003) Places of memory. A companion to political geography. 289-301. 
Tuan, Yi-Fu (1991) Language and the making of place: A narrative-descriptive approach, Annals of American Geographers 81: 684-696.

Turner C (2014) Flag Protests, Politics and Transition in Northern Ireland. Critical Legal Thinking Online 04 February. http://criticallegalthinking.com/2013/02/04/flagprotests-politics-and-transition-in-northern-ireland/ accessed 01 September 2016.

Tzfadia E (2008) Abusing multiculturalism: the politics of recognition and land allocation in Israel. Environment and Planning D: Society and Space 26 (6):1115-1130.

United Nations (1993) High Commission of Human Rights, UN General Assembly, 20 December 1993

United Nations (1951), Convention on the Prevention and Punishment of the Crime of Genocide, UN General Assembly (ratified 1948 UN General Assembly Resolution 260).

United Nations 1(976) International Covenant on Civil and Political Rights (adopted UN General Assembly adoption 1966).

Vallacher, R. R., Coleman, P. T., Nowak, A. and Bui-Wrzosinska, L (2010) Rethinking intractable conflict: The perspective of dynamical systems. American Psychologist, 65: $262-278$

Visoka G (2016) Peace Figuration after International Intervention: Intentions, Events and Consequences of Liberal Peacebuilding. London: Routledge.

Williams P (2015) Everyday peace?: politics, citizenship and Muslim lives in India. John Wiley \& Sons.

Williams P and McConnell F (2011) Critical geographies of peace. Antipode, 43(4), 927-931. 
